\title{
Етіологічні та патогенетичні чинники дисметаболічних нефропатій у дітей
}

Останніми роками спостерігають зростання поширеності дисметаболічних нефропатій у структурі захворюваності нирок у дітей. Обмінні нефропатії виявляють у 27-64\% всіх захворювань нирок дитячого віку. У роботі проаналізовано дані літератури для узагальнення найпоширеніших чинників патогенезу обмінних нефропатій дитячого віку. Доступні наукові джерела опрацьовано методами оглядового та системного аналізу. Проаналізовано дані сучасних досліджень опису спадкових і біохімічних факторів виникнення дисметаболічних нефропатій, особливості патогенезу оксалатних, уратних та цистинових нефропатій. На підставі вивчених джерел можна стверджувати, що не існує єдиної моделі, яка може пояснити патогенетичні зміни в різних складових канальцевого апарату залежно від спрямованості та сили дії несприятливого чинника. Для виявлення взаємозв'язку між рівнем інтерлейкінів та мінеральним обміном за умов дисметаболічних нефропатій потрібне подальше вивчення закономірностей, отриманих у результаті клініко-лабораторних, статистичних та епідеміологічних досліджень.

Ключові слова: дисметаболічні нефропатії у дітей, оксалатурія, уратурія, фосфатурія, інтерлейкіни.

\section{Вступ}

Сьогодні відзначають тенденцію до неухильного зростання нефрологічних захворювань серед дітей різного віку (Hernandez J.D. et al., 2015). Частота захворювань сечової системи у дітей має досить великий розмах коливань у широких межах, сягаючи 5,6-27,5 на 1000 дитячого населення, де дисметаболічні (обмінні) нефропатії займають чи не провідне місце - 27-64\% усіх захворювань (Стоева Т.В., 2011). У педіатричній практиці переважна більшість кристалурій та дисметаболічних нефропатій пов'язана з порушенням обміну кальцію - 70-90\%, причому близько 85-90\% - оксалатурії з переважанням виведення кальцію оксалату, меншу частину становлять фосфатурії (3-10\%), які частіше також є змішаними - оксалатно-фосфатно-уратними. Уратна кристалурія та уратний літіаз становлять біля 5\% випадків, цистинурія - до 3\%. У 5-15\% випадків виявляють трипельфосфати - фосфатні кристали, що містять іон амонію, магнію та кальцію. 3 урахуванням значної варіабельності показників частота дисметаболічних нефропатій у дітей, в тому числі в нашій країні, точно невідома, оскільки дані офіційної статистики не відображають справжньої поширеності цих захворювань (Anderson C.E. et al., 2015; Lee S.T., Cho H., 2016).

Мета роботи - проаналізувати дані літератури для узагальнення найпоширеніших чинників патогенезу обмінних нефропатій дитячого віку.

Вивчаючи дані наукової літератури з цього питання, можемо припустити, що, попри очевидний інтерес до проблеми спадкових та набутих метаболічних тубулопатій, багато аспектів чинників ризику, етіології та патогенезу досі залишаються не розкритими (Dwyer M.E. et al., 2012).

Дисметаболічними нефропатіями називають велику групу захворювань нирок з різними механізмами, які розвиваються внаслідок генетичних порушень обміну речовин - пуринового, оксалатного та/чи фосфатного. Зокрема йдеться про структурні порушення на рівні нефрону та зміни функціонального стану нирок, що виникають внаслідок цього (Bevill M. et al., 2017).

Вважають, що у процесі кристалоутворення важливу роль відіграють три принципові умови:

1) перенасичення канальцевої рідини солями, що перевищують межі її стабільності;

2) зниження активності інгібіторів перенасичення;

3) наявність активаторів преципітації (Gómez J. et al., 2016).

За таких умов пошкоджувальна дія на органи сечової системи здійснюватиметься за наявності >10 кристалів у сечовому осаді розміром >12 мкм (Pietrement C. et al., 2016).

Для утворення кристалів солей у сечі необхідна низка передумов, насамперед - наявність іонної пари у вигляді катіону та аніону. Перенасичення ними сечі зрештою призводить до подальшої преципітації у вигляді мікронефролітіазу. Важливу роль при цьому відіграє дегідратація сечі, що спричиняє собою підвищення концентрації іонів у сечі, навіть за нормальної їх продукції. Окрім ступеня насичення на розчинність іонів солей у сечі впливають: іонна сила, здатність до комплексоутворення, швидкість потоку сечі та ї̈ рH (Bevill M. et al., 2017).

Окремі особливості кристалоутворення безпосередньо залежать від виду обмінних порушень. Так, на кристалізацію сечової кислоти впливають рН сечі, її об'єм та добова екскреція. За умови кислих значень $\mathrm{pH}$ сечі сечова кислота знаходиться в оксоформі, при підвищенні рН розчинність сечової кислоти різко збільшується. Ймовірно, ці чинники і слугують тригерними механізмами метаболічних змін при уратній формі дисметаболічної нефропатії (Майданник В.Г. та співавт., 2013).

\section{Результати аналізу даних літератури}

У результаті аналізу даних літератури виявлено існування спільних рис для розвитку первинних форм дисметаболічних нефропатій. До них відносяться певний тип успадкування, морфологічний субстрат - ушкодження проксимального та дистального ниркових канальців, а також наявність ферментопатій, що пов'язані з дефіцитом або недостатньою активністю певних ензимів (Ingulli E.G., Mak R.H., 2014; Fanos V. et al., 2014).

Найбільш вивченою з усіх поки залишається первинна оксалатна нефропатія, при якій встановлено поєднання ознак оксалатного діатезу з антигенами гістосумісності I класу. Про це також свідчить достовірне переважання у цих пацієнтів фенотипу B7 та A28 (Almardini R.I. et al., 2014).

Первинна гіпероксалурія (оксалоз) включає три види генетично зумовлених порушень метаболізму гліоксилової кислоти, які характеризуються рецидивним оксалатно-кальцієвим нефролітіазом і розвитком хронічної ниркової недостатності (Степанова Н., 2016). Оксалатно-кальцієві кристали відкладаються в усіх тканинах організму, що призводить до оксалозу у віці до 10 років. Захворювання успадковується за аутосомно-рецесивним типом, проте відомі випадки домінантного носійства (Пиріг Л.А. та співавт., 2014).

Первинна гіпероксалурія 1-го типу (80\% випадків) спричинена мутаціями у гені аланінгліоксилатамінотрансферази, що кодує фермент аланінгліоксилаттрансферазу. Зниження активності цього ферменту, який каталізує перетворення гліоксилату у гліцин, призводить до підвищеного утворення оксалатів із гліоксилату (Gambaro G. at al., 2016). 
Первинна гіпероксалурія 2-го типу (10\% випадків) спричинена мутаціями в гені гліоксилатредуктази/гідроксипіруватредуктази - цитозольного ферменту, що каталізує перетворення гліоксилату на гліколат і гідроксипірувату в D-гліцерат у печінці та призводить до підвищеного утворення оксалатів та L-гліцерату (Konkol'ová J. et al., 2017).

Первинна гіпероксалурія 3-го типу (10\% випадків) спричинена мутаціями в гені DHDPSL, що кодує білок, схожий за структурою на фермент дигідродипіколинатсинтазу або 4-гідрокси2-оксоглутаратальдолазу, що експресується у печінці та нирках (Belostotsky R. et al., 2010).

Первинна уратна нефропатія - прогресуюче захворювання нирок, пов'язане з незбалансованістю урикоземії та урикозурії, яке, окрім усього, проявляється гематурією та/чи протеїнурією. Надалі цей патологічний стан загрожує розвитком тубуло-інтерстиційного нефриту та сечокам'яної хвороби (Таран О.І., 2013). Результати проспективних досліджень свідчать, що первинна уратна нефропатія виникає у пацієнтів зі спадково зумовленим дефектом метаболізму сечової кислоти (подагра, синдром Леша - Найхана) (Sayer J.A., 2017). Вказано, що спільним механізмом для цих нефропатій $є$ підвищена продукція пуринових основ, що зумовлює високий рівень 5-фосфорибозил-1-пірофосфату в клітинах та прискорює ланцюг реакцій деградації пуринів (Длин В.В., Османов И.М., 2013). За різними даними, первинну, чи справжню фосфатурію частіше виявляли у дітей із патологією центральної нервової системи. Такий тип нефропатії достовірно частіше діагностовано у дітей із нирковим канальцевим ацидозом, рахітоподібними захворюваннями тощо (Christov M., Jüppner H., 2013).

Одним із різновидів дисметаболічної нефропатії є ідіопатична гіперкальціурія, що визначається як підвищена екскреція кальцію з сечею при нормальному рівні кальцію в крові (>4 мг на 1 кг маси тіла пацієнта упродовж 24 год) (Balestracci A. et al., 2014). Вона пов'язана з підвищеним всмоктуванням кальцію в кишечнику, посиленою резорбцією кісткової тканини, первинним дефектом ниркових канальців, що призводить до втрати цього елементу з сечею, а також зі зміною чутливості рецепторів до вітаміну D (Figueres M.L. et al., 2015; Sayer J.A., 2017).

Останніми роками дослідники акцентують увагу на тому, що оксалати можуть утворюватися в нирках внаслідок руйнування фосфоліпідного шару клітинних мембран. При цьому формуються попередники оксалатів (серин), а також фосфати, з якими кальцій утворює нерозчинні солі (Yaseen A. et al., 2017). До безпосередніх причин розпаду мембранних фосфоліпідів відносять ішемію ниркових судин, активізацію ендогенних або появу бактеріальних фосфоліпаз, дію мембранотоксичних сполук, перш за все - вільних кисневих радикалів. У результаті оксидативного стресу порушується рівновага між відновленням та деструкцією мембрани у життєвому циклі - зі зміщенням у бік руйнування.Інтенсивний розвиток оксидації в нирковій тканині призводить до некрозу, але його уповільнення запускає механізми клітинного апоптозу (Kuwahara E. et al., 2017). Водночас даних літератури щодо етіопатогенетичної ролі оксидативного стресу в генезі та прогресуванні дисметаболічних нефропатій обмаль.

Окремо слід зупинитися на формах дисметаболічної нефропатії, які виникають на тлі гіпоксії, ішемії чи порушення біоелементного статусу. Відомо, що ця патологія нирок, зумовлена порушенням функції окремих частин нефрону, має зворотний характер і виникає на фоні дефіциту калію та магнію. При цьому в канальцях, на межі кіркової та мозкової речовини нирок, виявляють кристали оксалату кальцію. Відомо, що магній підвищує розчинність солей кальцію, і нестача його підвищує ризик утворення в нирках кальцієвих депозитів (Xiao X. et al., 2016).

Вторинна уратна нефропатія виникає як ускладнення при мієлопроліферативній хворобі, хронічній гемолітичній анемії, застосуванні низки препаратів (діуретики, нестероїдні протизапальні препарати, циклоспорин А тощо), впливі несприятливих екопатологічних факторів (отруєння свинцем, вплив радіації у малих дозах тощо). Вторинна фосфатурія нерідко спостеріга-

стья при порушеннях кальцієвого обміну і супроводжується гіперкальціурією. Вона пов'язана з порушеннями метаболізму вітамінів, захворюваннями центральної нервової системи, патологією паращитовидних залоз, уродженими аномаліями розвитку органів сечової системи, вегетаріанським харчуванням, інфекціями (Fanos V. et al., 2014; Gómez J. et al., 2016; Harambat J. et al., 2017).

Серед причин вторинних дисметаболічних нефропатій також медикаментозно-індуковані нефропатії. До препаратів, що провокують дисметаболічну нефропатію, відносять вітамін В у високих дозах, сульфаніламіди, антиметаболіти (метотрексат, меркаптопурин), деякі нестероїдні протизапальні препарати (індометацин), глюкокортикоїди - у разі тривалої терапії, фуросемід - як препарат, що пригнічує активність транспортних систем мембран ниркового епітелію (Rodieux F. et al., 2015)

Ще одним із вивчених патогенетичних механізмів ураження клітинних мембран є кальцифілаксія - особливий вид порушення кальцієвого обміну у дітей, спричинений підвищеною лабільністю їх поверхневого фосфоліпідного складу. У поняття цього оксалатного діатезу вкладається уявлення про схильність до розвитку оксалатної нефропатії на основі особливостей обміну щавлевої кислоти і/чи сімейної нестабільності цитомембран. Загострення цього діатезу найчастіше викликає дисметаболічну нефропатію з оксалатно-кальцієвою кристалурією та/ чи фосфатною кристалурією (Yaseen A. et al., 2017).

У циклі досліджень на культурі тканин та мишах зі специфічним фенотипом макрофагальної активності встановлено підвищену активність утворення оксалатних солей у нирках на фоні експресії інтерлейкіну-6 та фактора некрозу пухлини-а, водночас зі збільшенням активності індуцибельної NO-синтази. Спостерігали зниження кристалурії після введення препаратів інтерлейкіну-4 та -13 (Taguchi K. et al., 2016).

В експериментальному дослідженні S.R. Mulay та співавторів (2013) встановлено, що підвищення відкладання солей оксалатів кальцію в канальцях нирок призводить до активації секреції інтерлейкіну-1 через вісь NLRP3 (Nod-like receptor protein, або кріопірин) - ASC (apoptosis-associated speck-like protein) - каспаза-1. Деякі дослідники (Mulay S.R. et al., 2014) також пов'язують розвиток запального процесу з активацією цієї інфламасоми NLRP3, причому вказують на залежність прискорення синтезу інтерлейкіну-1 та -18 від підвищеного вмісту не тільки оксалатів у сечі, але й фосфатів. У невеликому клінічному дослідженні виявлено значне підвищення вмісту інтерлейкіну-1ß та -2 на фоні зростання кількості В-лімфоцитів та імуноглобуліну А у хворих з ускладненим уролітіазом (Ceban E. et al., 2017). У дослідженні B. Zhang та співавторів (2015) щодо асоціації між уролітіазом та поліморфізмом генів інтерлейкінів встановлено статистично вірогідні взаємовідношення між інцидентністю урикемії та частотою носійства генетично несприятливих варіантів поліморфізмів генів, що кодують інтерлейкін-8 та - 18

\section{Висновки та перспективи подальших досліджень}

Усі дисметаболічні нефропатії зрештою призводять до кристалізації кальцію в канальцях нирок з потенційним формуванням сечокам'яної хвороби, інтерстиційного нефриту, інфекційних ускладнень та хронічної ниркової недостатності. Водночас залишаються незрозумілими окремі аспекти етіопатогенезу, механізми успадкування первинних та вторинних нефропатій, а також вплив середовищних та ендогенних чинників на реалізацію патогенетичних механізмів та прогноз перебігу дисметаболічних нефропатій. Ці питання потребують додаткового вивчення.

Подальше дослідження слід проводити у напрямку спостереження когорти дітей із дисметаболічними нефропатіями з оцінкою середовищних, нозологічних факторів та визначенням особливостей мінерального обміну ти цитокінового балансу серед учасників цієї когорти.

Список використаної літератури

Длин В.В., Османов И.М. (2013) Дисметаболическая нефропатия с оксалатно-кальциевой кристаллурией. Эффект. фармакотер., 42: 8-16. 
Майданник В.Г., Бурлака Є.А., Багдасарова І.В. та ін. (2013) Клітинна гіпоксія як механізм пошкодження нирок при хронічному пієлонефриті у дітей. Совр. педиатр., 3(51): 132-135.

Пиріг Л.А., Іванов Д.Д., Таран О.І. та ін. (2014) Нефрологія: Націонал. підруч. Заславський 0.Ю., Донецьк, 292 с.

Степанова Н. (2016) Гіпероксалурія: механізми формування та наслідки (http://www.ukrinnd.com.ua/files/file/archive/n51/Stepanova.pdf).

Стоева Т.В. (2011) Профилактика при нефропатиях у детей. А.В. Зубаренко, Л.Г. Кравченко (ред.). Профил. педиатр., Одесса, Чорномор'я, с. 139 200.

Таран 0.I. (2013) Уратна нефропатія та основні підходи до їі лікування. Почки, 2(04) (http://www.mif-ua.com/archive/article/36059).

Almardini R.I., Alfarah M.G., Salaita G.M. (2014) The clinical pattern of primary hyperoxaluria in pediatric patient at Queen Rania Abdulla Children Hospital. Arab. J. Nephrol. Transplant., 7(2): 119-123.

Anderson C.E., Gilbert R.D., Elia M. (2015) Basal metabolic rate in children with chronic kidney disease and healthy control children. Pediatr. Nephrol., 30(11): 1995-2001.

Balestracci A., MeniBattaglia L., Toledo I. et al. (2014) Idiopathic hy percalciuria in children with urinary tract infection. Arch. Argent. Pediatr., 112(5): 428-433.

Belostotsky R., Seboun E., Idelson G.H. et al. (2010) Mutationsin DHDPSL are responsible for primary hyperoxaluria type III. Am. J. Hum. Genet., 87(3): 392-399.

Bevill M., Kattula A., Cooper C.S. et al. (2017) The Modern Metabolic Stone Evaluation in Children. Urology, 101: 15-20.

Ceban E., Banov P., Galescu A., Tanase D. (2017) The cellular and humoral immunity assay in patients with complicated urolithiasis. J. Med. Life, 10(1): 80-84.

Christov M., Jüppner H. (2013) Insights from genetic disorders of phosphate homeostasis. Semin. Nephrol., 33(2): 143-157.

Dwyer M.E., Krambeck A.E., Bergstralh E.J. et al. (2012) Temporal trends in incidence of kidney stones among children: a 25 -year population based study. J. Urol., 188(1): 247-252.

Fanos V., Noto A., Caboni P. et al. (2014) Urine metabolomic profiling in neonatal nephrology. Clin. Biochem., 47(9): 708-710.

Figueres M.L., Linglart A., Bienaime F. et al. (2015) Kidney function and influence of sunlight exposure in patients with impaired 24-hydroxylation of vitamin D due to CYP24A1 mutations. Am. J. Kidney Dis., 65(11): 122-126.

Gambaro G., Croppi E., Coe F. at al. (2016) Metabolic diagnosis and medical prevention of calcium nephrolithiasis and its systemic manifestations: a consensus statement. J. Nephrol., 29(6): 715-734.

Gómez J., Gil-Peña H., Santos F. et al. (2016) Primary distal renal tubular acidosis: novel findings in patients studied by next-generation sequencing. Pediatr. Res., 79(3): 496-501.

Harambat J., Kunzmann K., Azukaitis K. et al. (2017) Metabolic acidosis is common and associates with disease progression in children with chronic kidney disease - 4C Study Consortium. Kidney Int., 17: 30330-30337.

Hernandez J.D. , Ellison J.S., Lendvay T.S. (2015) Management of Pediatric Nephrolithiasis. Current Trends, Evaluation, and treatment. JAMA Pediatr., 169(10): 964-970.

Ingulli E.G., Mak R.H. (2014) Growth in children with chronic kidney disease: role of nutrition, growth hormone, dialysis, and steroids. Curr. Opin. Pediatr., 26(2): 187-192.

Konkol'ová J., Chandoga J., Kováčik J. et al. (2017) Severe child form of primary hyperoxaluria type 2 - a case report revealing consequence of GRHPR deficiency on metabolism. BMC Med. Genet., 18(1): 59.

Kuwahara E., Murakami Y., Okamura T. et al. (2017) Increased childhood BMI is associated with young adult serum uric acid levels: a linkage study from Japan. Pediatr. Res., 81(2): 293-298.

Lee S.T., Cho H. (2016) Metabolic features and renal outcomes of urolithiasis in children. Ren. Fail., 38(6): 927-932.

Mulay S.R., Evan A., Anders H.-J. (2014) Nephrol Molecular mechanisms of crystal-related kidney inflammation and injury. Implications for cholesterol embolism, crystalline nephropathies and kidney stone disease. Dial. Transplant., 29(3): 507-514.

Mulay S.R., Kulkarni O.L., Rupanagudi K.V. et al. (2013) Calcium oxalate crystals induce renal inflammation by NLRP3-mediated IL-1 $\beta$ secretion. Clin. Invest. 123(1): 236-246.

Pietrement C., Allain-Launay E., Bacchetta J. et al. (2016) Diagnosis and management of chronic kidney disease in children: Guidelines of the French Society of Pediatric Nephrology. Arch. Pediatr., 23(11): 1191-1200.

Rodieux F., Wilbaux M., van den Anker J.N., Pfister M. (2015) Effect of kidney function on drug kinetics and dosing in neonates, infants, and children. Clin. Pharmacokinet., 54: 1183-1204.
Sayer J.A. (2017) Progress in understanding the genetics of calcium-containing nephrolithiasis. J. Am. Soc. Nephrol., 28(3): 748-759.

Taguchi K., Okada A., Hamamoto S. et al. (2016) $\mathrm{M}_{1} / \mathrm{M}_{2}-$-macrophage phenotypes regulate renal calcium oxalate crystal development. Sci. Rep., 6: 35167.

Xiao X., Dong Z., Ye X. et al. (2016) Association between OPN genetic variations and nephrolithiasis risk. Biomed. Rep., 5(3): 321-326.

Yaseen A., Tresa V., Lanewala A.A. et al. (2017) Acute kidney injury in idiopathic nephrotic syndrome of childhood is a major risk factor for the development of chronic kidney disease. Ren. Fail., 39(1): 323-327.

Zhang B., Sun Y., Li Y. et al. (2015) Association analysis between genetic variants in interleukin genes among different populations with hyperuricemia in Xinjiang Autonomous Region. Int. J. Clin. Exp. Pathol., 8(10): 13432-13440.

\section{Этиологические и патогенетические факторы дисметаболических нефропатий у детей}

\section{Н.P. Айб}

Резюме. В последние время отмечено повышение распространенности дисметаболических нефропатий в структуре заболеваемости почек у детей. Обменные нефропатии составляют 27-64\% заболеваний почек детского возраста. В работе проанализированы данные литературы о наиболее распространенных факторах патогенеза обменных нефропатий детского возраста. Доступные научные источники проработаны методами обзорного и системного анализов. Проанализированы данные современных исследований с описанием наследственных и биохимических факторов возникновения дисметаболическихнефропатий, особенности патогенеза оксалатных, уратных и цистиновых нефропатий. На основании изученных источников можно утверждать, что не существует единой модели, объединяющей патогенетические изменения в разных составляющих канальцевого аппарата в зависимости от направленности и силы действия неблагоприятного фактора. Для выявления взаимосвязи между уровнем интерлейкинов и состоянием минерального обмена при дисметаболических нефропатиях необходимо дальнейшее изучение закономерностей, полученных в результате клинико-лабораторных, статистических и эпидемиологических исследований

Ключевые слова: дисметаболические нефропатии у детей, оксалатурия, уратурия, фосфатурия, интерлейкины.

\section{Etiologic and pathogenetic factors of dysmethabolic nephropathies in children}

\section{N.R. Aib}

Summary. Recently the growth of prevalence of dysmethabolic nephropathy in the structure of kidney morbidity in children is observed. Dysmethabolic nephropathy takes 27-64\% among all structure of kidney diseases of children. Data of the literature about the most common factors of pathogenesis of methabolic nephropathy in children were analized. Available scientific sources dedicated to the mechanisms of development of the dysmethabolic nephropathy, studied by the methods of overview and system analyses. The results of the modern studies with description of the inherited and biochemical factors as substantial for origin of the nephropathy, were analyzed, as well as the features in pathogenesis of oxaluria, uraturia and cystinic nephropathy. On the basis of the studied sources it is possible to assert that there is no specific model which can explain pathological changes in different parts of kidney structure depending on direction of action of unfavorable factor. For the exposure of association between interleukin content and the state of mineral methabolism in dysmethabolic nephropathy the further study of patterns obtained on the basis of clinical, laboratory, statistical and epidemiological studies are necessary.

Key words: dysmethbolic nephropathy in kids, oxaluria, uraturia, phosphaturia, interleukins.

\section{Адреса для листування:}

Айб Надія Романівна

76000, Івано-Франківськ, вул. Галицька, 2

Івано-Франківський національний медичний університет,

кафедра педіатрії 